\title{
Recalling Victory, Recounting Greatness: Second World War Remembrance in Xi Jinping's China
}

\author{
Vincent K.L. Chang ${ }^{*}$
}

\begin{abstract}
The recent surge in public remembrance of the Second World War in China has been substantially undergirded by a centrally planned and systematically implemented discursive shift which has remained overlooked in the literature. This study examines the revised official narrative by drawing on three cases from China's school curriculum, museums and formal diplomacy. It finds that the once dominant trope of "national victimization" no longer represents the main thrust in the Chinese Communist Party's (CCP) rhetoric on the Second World War. Under Xi Jinping, this has been replaced by a self-assertive and aspirational narrative of "national victory" and "national greatness," designed to enhance Beijing's legitimacy and advance its domestic and foreign policy objectives. By emphasizing national unity and CCP-KMT cooperation, the new narrative offers an inclusive and unifying interpretation of China's war effort in which the victory in 1945 has come to rival the 1949 revolution as the critical turning point towards "national rejuvenation." The increasingly Sino-centric and centrally controlled narrative holds implicit warnings to those challenging Beijing's claim to greatness.
\end{abstract}

Keywords: China's War of Resistance against Japan; Second World War; official memory; patriotic education; history textbooks; museum narratives; national rejuvenation

Since becoming the general secretary of the Chinese Communist Party (CCP) in 2012, Xi Jinping 习近平 has pushed an agenda of reviving the memory of the "Chinese people's war of resistance against Japanese aggression and the world anti-fascist war," as the Second World War is officially known in China. Within three years of taking office, Xi had extended the war's time frame from eight to fourteen years, overseen an unprecedented military parade at Tiananmen Square and established two new official remembrance days. The

* Prior affiliation: Southwest University, China War of Resistance "Dahoufang" Research Center, Chongqing, China. Current affiliation: Leiden University, The Netherlands. Email: v.k.chang@hum.leidenuniv.nl. 
decision of the National People's Congress in 2014 to designate 13 December as a national day of commemoration of the Nanjing Massacre - when Japanese imperial troops slaughtered and raped thousands of citizens of China's then capital and pillaged the city in a six-week killing spree - raised eyebrows across the world, not least in Japan, where officials questioned Beijing's renewed interest in Japan's wartime conduct. ${ }^{1}$

The official Chinese discourse of national humiliation and victimization, accompanied by a political "numbers game" aimed at quantifying and denouncing Japanese war atrocities, emerged during the late 1990s and early 2000s as a paradigm of Chinese war remembrance, replacing the discourse of the Maoist era. ${ }^{2}$ Despite the notable shifts in China's commemorative practices in recent years, the "national victimization" paradigm has continued to function as the standard interpretative framework in the academic literature, coupled with a predominant focus on the Nanjing Massacre as the quintessential event of China's war remembrance. ${ }^{3}$

Given the country's evolving global status, ambitions and pretentions, some authors have asked recently whether it is still fitting for the Chinese leadership to espouse such a passive and powerless victimhood discourse. ${ }^{4}$ The present study suggests that this question overlooks a paradigm shift which has underpinned the recent wave of commemoration under Xi Jinping. This shift comprises a centrally planned and implemented move away from the earlier victimization narrative towards a new, more powerful retelling of the history of the Second World War. I use three representative cases to argue that elements of the two earlier paradigms have been repackaged and remixed into a unifying and empowering new reading that emphasizes national victory and national greatness, thereby reflecting China's changed place in international society and the CCP's evolving policy goals.

The basic parameters of this shift were first outlined by Xi during a Politburo meeting held on 31 July 2015 to review the history of China's War of Resistance. The purpose of the review, as explained by $\mathrm{Xi}$, was to acknowledge the "great contribution" made by the Chinese people towards victory in the Second World War and hence towards international peace and justice, and to affirm that the Chinese people should "never forget the past" and "create a positive attitude for the future." 5 During the meeting, Xi observed that research on the war remained far from adequate, given the war's "historical significance" and its

1 “Japan 'puzzled' by new China war events.” SBS News, 28 February 2014, https://www.sbs.com.au/ news/japan-puzzled-by-new-china-war-events. Accessed 1 November 2019.

2 Waldron 1996; Zhao, Suisheng 1998; Mitter 2000; Gries 2004. On the "numbers game," see Coble 2007, 394.

3 Liu 2009; Wang, Xiaokui 2017; Qian and Liu 2019.

4 Foot 2019, 143, 157; Qian and Liu 2019, 83-84.

5 "Xi Jinping: rang lishi shuo hua yong shishi fayan, shenru kaizhan Zhongguo renmin kang-Ri zhanzheng yanjiu" (Xi Jinping: let historical facts speak, deepen the research on the Chinese people's War of Resistance against Japan). Xinhuanet, 31 July 2015, http://www.xinhuanet.com//politics/2015-07/31/ c_1116107416.htm. Accessed 1 November 2019. 
"influence on the Chinese nation and the world." Urging historians to study the 14-year war as an integrated whole, he called on them to focus on three core aspects: the "great significance" of the Chinese people's war, its "important place" in the global fight against fascism, and the "central role" of the CCP as the "key" to ultimate victory. As if to respond to his own call, Xi then provided an assessment of the historical significance of the war, stating that it "re-established China's status as a great power in the world, won the Chinese people the respect of peace-loving people of the world, [and] opened up the prospect of the great rejuvenation of the Chinese nation."6

This assessment would form the core of subsequent public commemorations and representations of the war. The remarkable rhetorical changes reflected in these representations point at a carefully conceived and systematically implemented decision not only to bring the official narrative on the Second World War into line with Beijing's present aims and ambitions but also to target these more effectively to domestic, regional and global audiences. This article examines how this top-down project has since taken shape. It focuses on three cases, drawn from the school curriculum, museum exhibitions and formal diplomacy, each of which is analysed in accordance with a basic framework identifying the major themes, seats of agency, dichotomies and historical "lessons." Before analysing these three cases, however, the next section puts the latest developments into relief by outlining the two preceding paradigms using a similar basic frame of analysis.

\section{War Remembrance before Xi: Two Interpretative Paradigms}

The development of Second World War discourse in the People's Republic of China (PRC) reflects the complex evolving relationship between the CCP and Chinese society. ${ }^{7}$ This section draws from the available literature to outline the two narrative paradigms that most scholars agree shaped official war remembrance in China from 1949 until the beginning of the current millennium. This review provides the key points of reference for the assessment of the more recent instances of Second World War commemoration discussed in the subsequent sections of this article.

\section{Revolutionary heroism}

The first paradigm characterized the official discourse on the Second World War during the Maoist years, when Beijing was engaged domestically in ideological campaigns and globally with exporting the Socialist revolution. According to this narrative, the CCP single-handedly led the Chinese people to victory in a war waged not against the Japanese nation as such, but rather against a ruling clique of Japanese militarists aided by Chinese feudalist traitors - that is, the

7 Reilly 2011, 466. 
diehard Chinese Nationalists (Kuomintang or KMT) coalescing around Chiang Kai-shek 蒋介石. ${ }^{8}$ The war was thus presented as a transnational struggle between progressive and reactionary forces, based on a dichotomy juxtaposing the CCP's revolutionary fervour, heroism and triumph with KMT callousness, cowardice and defeatism, and leaving little room for recalling Chinese victimhood or Japanese atrocities. ${ }^{9}$ With resistance and collaboration framed almost exclusively along partisan-political lines, the main agency in this metanarrative was vested in the CCP as the vanguard - leader, tutor and liberator - of the Chinese people. The war itself thus had little inherent significance, featuring in Chinese historiography as a "mere way-station on the path to CCP dominance in 1949." 10 If there was a lesson to be learned from the war, it was evoked in Mao's observation in April 1945 that "without the efforts of the CCP and without the CCP as the mainstay of the Chinese people, China's independence and liberation would not have been possible." 11 It is this message that shaped the main narratives in "Red" heritage sites and museums across the country, such as the Revolutionary Memorial Hall in Yan'an 延安 (the de facto CCP capital during the Second World War) and the former Museum of the Chinese Revolution (now the National Museum) in Beijing, founded in the 1950s and early 1960s. The emphasis on revolution in these historical representations was so pervasive that public memory of the war itself had virtually disappeared in China by the time of Mao's death in $1976 .{ }^{12}$ Aside from domestic politics, there were also geopolitical motives - for example, mollifying Tokyo to balance Washington and Moscow - for the CCP leadership to avoid nationalist retellings of the war and promote what James Reilly has termed a "benevolent amnesia."13

\section{National victimization}

While the "revolutionary heroism" theme never disappeared from Chinese Second World War discourse, there is broad consensus that it was supplanted as the central paradigm in the late 1980s by a nationalistic metanarrative depicting the Chinese nation as the victim of a long series of hostile interventions by foreign states, culminating in Japan's invasion of (parts of) China between 1931 and $1945 .{ }^{14}$ This paradigm shift has been understood as a response both to the ideological vacuum and credibility crisis that the CCP suffered domestically in the wake of several disastrous political campaigns and the Tiananmen Square protests, and also to the geopolitical recalibration prompted by the collapse of the Soviet Union. As Tokyo lost its strategic value to Beijing as a

8 Wang, Zheng 2008, 789-790; Wang, Xiaokui 2017, 329.

9 Brook 2008, 12.

10 Mitter 2010, 86.

11 Mao 1949, 83-84.

12 Waldron 1996, 949; Coble 2007, 395.

13 Reilly 2011, 468-69; see also Hatch 2014, 372.

14 See Waldron 1996; Zhao, Suisheng 1998; Mitter 2000; Gries 2004. 
de facto ally against Moscow, and the CCP reverted to nationalism to shore up its floundering claims to legitimacy, Japan became the new national nemesis, taking on the role of the external "other" in China's new identity politics. ${ }^{15}$ The theme of national victimization and suffering at the hand of the Japanese was at the heart of the "patriotic education campaigns" that pervaded schools and museums across the country. ${ }^{16}$ This state-led nationalism at home went hand in hand with a fervent "apology diplomacy" in the international sphere aimed at extracting political concessions from Japan. ${ }^{17}$

The aggressor-victim dichotomy that characterized the "new remembering" implied a shift of agency away from the CCP to "evil Japan," with the Chinese people now being represented as passive and powerless. ${ }^{18}$ On the flip side, it gave rise to a much more benign view of the Chinese Nationalists, who were now regarded as fellow victims and martyrs instead of traitors. ${ }^{19}$ This culminated in 2005 with President Hu Jintao 胡锦涛 publicly commemorating four high-ranking Nationalist generals, recalling their sacrifice on China's Second World War battlefields and putting them on an equal footing with four fallen CCP heroes. ${ }^{20}$ This reconciliatory attitude towards the Kuomintang and other pan-Blue groups in Taiwan aligned well with Beijing's geostrategic considerations during the reform and opening-up era, which were premised in part on promoting cross-Strait cooperation and exchange.

The victimhood narrative is most strongly associated with historical sites of major wartime atrocities, notably in the former Nationalist capital Nanjing and in north-east China, where the Japanese military conducted biological and chemical warfare experiments on Chinese civilians. During the 1980s and 1990s, several museums and remembrance halls sprang up in the north-east, including the Memorial Hall of the Victims of the Nanjing Massacre and the Unit 731 Museum in Harbin. The key historical "lesson" propounded by these representations, and reinforced by Chinese media reports and academic publications, was that China's war experience must be remembered in order to counter the efforts of right-wing political forces in Japan to whitewash history and jeopardize global peace. ${ }^{21}$

\section{War Remembrance under Xi: Three Cases}

On 3 September 2015, world leaders and global audiences watched as Xi delivered a 12-minute televised address from the rostrum of the Tiananmen Gate to commemorate the 70th anniversary of V-J Day. ${ }^{22}$ As presaged in his remarks

15 Denton 2014, 135; Rozman 2010, 156, 162-63.

16 Zhao, Suisheng 1998; Wang, Zheng 2008.

17 Gries 2004, 90-94.

18 Foot 2019, 143, 157; Qian and Liu 2019, 83-84.

19 Coble 2007; Zhang, Qiang, and Weatherley 2013

$20 \mathrm{Hu}$, Jintao 2005.

21 Liu 2009; Li, Hongtao, and Huang 2014; Li, Xin 2017; Wang, Guangtao 2017.

22 Xi 2015. 
at the Politburo meeting six weeks before, Xi's speech differed from those of his predecessors in a number of significant ways. A first major departure was the strong emphasis on China's victory. In the first half of his speech, Xi used the word "victory" (shengli 胜利) 12 times, often in combination with the words “great" (weida 伟大) and the "Chinese people" (Zhonguo renmin 中国人民). In stark contrast to Jiang Zemin's 江泽民 address in 1995 and that of Hu Jintao in 2005, there was no mention of the Nanjing Massacre or any other Japanese atrocities. ${ }^{23}$ Where Xi did refer to China's "national sacrifice," this served solely to underline the unity and courage displayed by the unyielding Chinese people in winning "total victory." Another striking aspect was the explicit link that Xi made between the history of the war and contemporary politics. This was done by framing China's hard-won victory as a historical anchor point not just of China's national "rejuvenation" but also of Beijing's current efforts to contribute CCP-styled concepts of governance to the international system, including the "community of common destiny for mankind" and "win-win cooperation." This section examines how Xi's historical reinterpretation and discursive innovations are being disseminated and implemented through the school curriculum, museum exhibitions and formal diplomacy.

\section{School curriculum: revision of middle-school history textbooks}

History textbooks aim to convey the essential lessons of history to new generations and hence are an "ideal medium" for transmitting political propaganda and fostering patriotic sentiment. ${ }^{24}$ In China's authoritarian system, the teaching materials used by primary and secondary schools must not only reflect "the will of the CCP and the state" but also, according to recently amended regulations, "guide students to become bearers of the great responsibility of rejuvenation of the Chinese nation." 25 To this end, history textbooks are standardized and unified under the auspices of the state. ${ }^{26}$ In July 2017, the main publishing house of the Ministry of Education, the People's Education Press, issued a new history textbook for the second grade of middle schools nationwide, replacing the previous 2013 edition. ${ }^{27}$ The book covers China's modern history, from the First Opium War through to the "liberation" of 1949, in eight units. Unit six, which comprises five chapters (lessons), is dedicated exclusively to the 14-year history of China's War of Resistance. As the principal author, Huang Yunlong, notes

$23 \mathrm{Hu}$, Jintao 2005. See also Qian and Liu 2019, 91.

24 Zhao, Suisheng 1998, 292-93; Weatherley and Magee 2018, 48.

25 “Jiaoyubu guanyu yinfa 'Zhong-xiaoxue jiaocai guanli banfa' de tongzhi" (Notice of the Ministry of Education on promulgating the administrative measures for teaching materials for primary and secondary schools), 2019, Art. 3, http://www.moe.gov.cn/srcsite/A26/moe_714/202001/t20200107_414578.html. Accessed 10 August 2020.

26 Ibid., Art. 4. The contents of these textbooks are censored by the CCP's Central Propaganda Department; see Weatherley and Magee 2018, 49.

27 See Renmin jiaoyu chubanshe 2017. I thank Sanne Albers of the University of Amsterdam for providing a copy of the textbook. On the 2013 textbook, see Weatherley and Magee 2018. 
in an introduction published in the journal Lishi jiaoxue 历史教学, the unit on China's war history is the most elaborate one (fenliang zui zhong 分量最重) in the book. ${ }^{28}$

The five chapters in this unit are organized thematically, presenting a coherent and compelling narrative that nonetheless proceeds in roughly chronological order. Thus, chapter 18 deals with the first six years, from the Manchurian incident of 1931 to the Xi'an incident of 1936; chapter 19 with the Marco Polo Bridge Incident and the outbreak of full-scale war in July 1937; chapter 20 with resistance at China's main battlefronts; chapter 21 with resistance behind the frontlines; and chapter 22 with final victory. Both this thematic arrangement and the substantive contents of the lessons are significant departures from previous editions. ${ }^{29}$ The primary aim of the overhaul, as Huang points out, was to highlight four key points: (1) the 14-year history of the War of Resistance should be viewed as a whole; (2) the CCP served as the mainstay of national unity and resistance by the Chinese people; (3) the Chinese battleground was the main eastern battlefield of the Second World War; and (4) the fighting at the frontlines (mainly by the KMT) and behind the frontlines (mainly by the CCP) reinforced each other and jointly constituted China's war effort.

Along with other elements of the narrative, these four points correspond closely to the innovations put forward by Xi Jinping at the July 2015 Politburo meeting and on various subsequent occasions. Particularly notable are the overwhelming emphasis on China's "great victory" and the corresponding lack of attention to Chinese victimhood and suffering. Chapter 19 does contain a passage on the Nanjing Massacre, citing (and illustrating) some of the most ghastly war crimes committed by Japanese troops during their invasion of the city, but it does not elaborate or provide any quantifications other than a single reference to the death toll of "over 300,000," as established in 1946 by the Nanjing War Crimes Tribunal. ${ }^{30}$ All in all, the five chapters contain very few references to Japanese atrocities, completely disregarding, for example, the testing of biological and chemical weapons on Chinese prisoners in north-east China or the protracted air raids on China's war capital, Chongqing.

Instead, the narrative goes to great lengths to emphasize Chinese military successes. These include key wins by the CCP's Eighth Route Army, such as the “smashing victory" (dajie 大捷) at Pingxingguan 平型关 in September 1937. This event is portrayed as a pivotal moment in China's resistance, marking the end of the myth of Japanese invincibility and hence - along with other CCP successes in (guerrilla) warfare - laying the foundation for ultimate victory. ${ }^{31}$ Also included, however, are accounts of successes and bravery that had been previously omitted from mainland Chinese textbooks: those led by Nationalist troops

28 Huang 2017, 57. Huang Yunlong is senior editor of the history editorial office of the People's Education Press; Qi Shirong was listed as the textbook's chief editor.

29 Huang 2017, 57.

30 Renmin jiaoyu chubanshe 2017, 94.

31 Ibid., 100, 102. 
engaged in conventional warfare at the front, such as the Battle of Wuhan (1938) and the Third Battle of Changsha (1944). ${ }^{32}$ Subtle shifts of agency in the way the narrative deals with these feats of bravery ensure that the key role of the KMT goes unacknowledged: whereas victories in China's occupied areas are attributed plainly to the CCP, successes in major battles on the frontline were scored by the “Chinese military” (Zhongguo jundui 中国军队). Only when recounting failure, defeatism or dubious judgement - such as the abandonment of Nanjing on the eve of the massacre, Wang Jingwei's 汪精卫 betrayal, and Chiang's decision in June 1938 to flood the Yellow River - does the text explicitly mention the Nationalists. ${ }^{33}$

The historiographical device facilitating this fluid but generally inclusive form of Chinese agency is the rehabilitation of the Second United Front. ${ }^{34}$ This wartime KMT-CCP pact was formed in the summer of 1937 following years of continued pressure from patriotic forces across the country, including the Communists. Consigned to oblivion during the Maoist years, the Second United Front now features in Chinese historiography as a major achievement of the CCP and the principal cause of ultimate victory. The key "lesson" of China's war history, spelled out in chapter 22 of the textbook, is thus firmly tied to the root causes of victory: the war caused a national awakening; the CCP accomplished unprecedented national unity; and the resultant resistance by the Chinese people led to Japan's defeat. ${ }^{35}$ In other words, the CCP was not the sole agent of Chinese victory, which can be credited to the Chinese nation as a whole, including rival domestic groups. But without the $\mathrm{CCP}$, China's war effort would have collapsed long before victory could be achieved. Mention of Chinese wartime collaboration and KMT-CCP rivalry is confined to brief, passing references. ${ }^{36}$ Rather than ignoring or disputing KMT successes, the CCP is thereby able to claim them as their own.

As inclusive and domestically empowering as the narrative might be in recounting the Chinese war effort, it is decidedly exclusive in how it deals with the international aspects of the war. The Allies barely feature in the narrative, except when they suffer defeats (such as in early 1942) or when there is no alternative but to acknowledge the role of the major powers (mainly the US and Britain). ${ }^{37}$ Even when they are mentioned, the emphasis is on how these "peaceloving countries and peoples" came to support China's just cause. In this highly China-centred account, devoid of transnational perspectives or comparison (but also of empathic forms of "othering"), the Chinese people reciprocated this

32 Huang 2017, 57.

33 Renmin jiaoyu chubanshe 2017, 93, 95, 97, 104.

34 Ibid., 87-89, 92. Also Zhang, Qiang, and Weatherley 2013, 223.

35 Renmin jiaoyu chubanshe 2017, 98, 107-08.

36 Ibid., 104. The South Anhui Incident of 1941, which according to earlier interpretations marked the KMT's betrayal and the de facto collapse of the United Front, has been relegated in the latest edition to a literal footnote.

37 Ibid., 98, 106. 
foreign support by fighting the Japanese in British Burma (between 1942 and 1945) and pinning down the great majority of Japan's fighting force on Chinese soil throughout the war, thereby "greatly contributing" to the global anti-fascist war and to global peace. ${ }^{38}$

\section{Museum exhibitions: overhaul of China's national resistance war museum}

Museums are important institutions for the CCP through which it attempts to shape public memory in the service of Party legitimacy and national unity. ${ }^{39}$ The PRC Law on the Protection of Cultural Relics, last amended in 2015, stipulates that exhibitions of cultural relics are to "strengthen the propaganda and education of the splendid historical culture and revolutionary traditions of the Chinese Nation."40 According to Kirk Denton, the Chinese party-state uses museums to assert changes in domestic policy and to present positive images, both to the Chinese people and to foreigners. ${ }^{41}$ Some scholars have recently turned away from state-centred perspectives and official narratives in studying China's museums, highlighting instead the agency of non-state actors and the growing cultural and social diversity of museum curation. ${ }^{42}$ This trend, however, should not be taken as an indication of waning state control. On the contrary, the CCP continues to exert a profound influence over China's museum exhibitions, particularly where historical narratives are involved. ${ }^{43}$ If anything, the Party's grip on these narratives has tightened in recent years. In 2018, it issued guidelines for enhancing the protection and utilization of "revolutionary" cultural relics nationwide. With a view to "carrying out patriotic education, cultivating socialist core values and realizing the great rejuvenation," the guidelines provide for increased central coordination and oversight of subnational representations of several pivotal events in China's revolutionary history, including the War of Resistance against Japan. ${ }^{44}$

The primary site for studying official Chinese narratives on the Second World War is the Museum of the War of Chinese People's Resistance against Japanese Aggression (Zhongguo renmin kang-Ri zhanzheng jinianguan 中国人民抗日战 争纪念馆). It is a first-grade national museum (guojia yiji bowuguan 国家一级 博物馆) located in the Chinese capital and the only official facility in the country

38 Ibid., 99, 108.

39 Denton 2014, 3; Pozzi 2020, 1.

40 Zhongguo renmin gongheguo wenwu baohu fa (Cultural Relics Protection Law of the People's Republic of China), Art. 40, http://www.npc.gov.cn/wxzl/gongbao/2015-08/10/content_1942927.htm. Accessed 10 August 2020.

41 Denton 2014, 6.

42 Varutti 2014; Ho 2019.

43 Denton 2014, 3-5.

44 "Zhonggong zhongyang bangong ting guowuyuan bangong ting yinfa 'guanyu shishi geming wenwu baohu liyong gongcheng (2018-2022 nian)' de yijian" (Opinion on the implementation of the "Revolutionary cultural relics protection and utilization project (2018-2022)" issued by the General Office of the CCP and the General Office of the State Council), http://www.xinhuanet.com/politics/ 2018-07/29/c_1123192714.htm. Accessed 10 August 2020. 
to commemorate the entirety of the war, thus effectively serving as the national centre for remembering China's War of Resistance. ${ }^{45}$ Targeting domestic as well as international audiences, its function is to serve as a patriotism education base, a historical research centre and both a "window for non-governmental exchanges with foreign countries and a bridge to connect with compatriots in Hong Kong, Macao and Taiwan and overseas Chinese." 46 Ten years after its founding in 1987, the museum was included in the first batch of "National patriotism education and demonstration bases" (Quanguo aiguozhuyi jiaoyu shifan jidi 全国爱国主义教育示范基地), which are tasked with promoting national unity and territorial integrity under the auspices of the CCP Central Propaganda Department. ${ }^{47}$ The museum operates directly under the auspices of the Beijing propaganda department and serves as a major "Red tourism" base in the city, receiving large numbers of cadres and school children among its million-plus annual visitors. ${ }^{48}$ In July 2014, Xi Jinping presided over a high-profile, nationally televised commemoration service held at the museum to mark the 77 th anniversary of the Marco Polo Bridge Incident. On 3 September 2020, amid the Covid-19 pandemic, the seven members of the Politburo Standing Committee of the $\mathrm{CCP}$, presided over by $\mathrm{Xi}$, attended a slightly subdued yet widely publicized event at the museum to commemorate the 75th anniversary of the victory of the war. ${ }^{49}$ Despite its prime importance in China's Second World War memoryscape, the museum has gained relatively little scholarly attention - far less than the Nanjing Massacre Memorial Hall - and the few analyses that do exist are of earlier versions of the main exhibition..$^{50}$

The permanent exhibition's current incarnation, entitled "Great victory, historical contribution” (Weida shengli, lishi gongxian 伟大胜利, 历史贡献), was launched in August 2015 to mark the 70th anniversary of the end of the Second World War. The phrase "great victory" first emerged in the exhibition title during a major renovation in 2005. This signalled the beginning of a gradual shift from an emphasis on victimhood towards a more empowering retelling of China's war experience, although the focus in the 2005 exhibition was still on Japanese atrocities and Chinese suffering. ${ }^{51}$ This changed following the 2015 makeover of the exhibition, with the new narrative, outlined in Table 1, having been updated and revised to align with Xi Jinping's new, more triumphalist reading of the history of the Second World War.

45 “Guanzhang zhici” (Director's statement), http://www.1937china.com/kzjng/views/bgjs/bgjs_zc.html. Accessed 8 September 2020.

46 Ibid

47 Zhao, Suisheng 1998, 296.

48 "Guanzhang zhici," see note 45.

49 "Xi Focus: Xi attends commemoration of 75th victory anniversary of anti-Japanese war, WWII." Xinhuanet, 3 September 2020, http://www.xinhuanet.com/english/2020-09/03/c_139339751.htm. Accessed 3 September 2020 .

50 See, e.g., Mitter 2000; Denton 2014; Hatch 2014. Mitter and Denton analyse the 1997 version of the main exhibition; Hatch analyses the 2005 version.

51 Denton 2014, 139-140. 


\section{Section title}

Preface

1 "Parts of China embark on a War of Resistance"

2 "The entire nation embarks on a War of Resistance"

3 "The firm mainstay"

4 "Atrocities conducted by the Japanese armed forces"

5 "The main battlefront in the East"

6 "A just cause will gain wide support"

7 "Great victory"

\section{Narrative outline}

The War of Resistance was a just war fought and won by the Chinese people under CCP leadership. As China's first victory against foreign imperialist aggression, it was a turning point in history and in the march towards national rejuvenation. As the first country to resist fascism and the main battlefield in Asia, China contributed significantly to world peace.

The Japanese invasion of Manchuria in 1931 marked the beginning of the war. While the KMT adopted a policy of appeasement, the CCP organized resistance in the north-east and launched national awakening campaigns across China. It successfully pushed for the creation of a national United Front, which became the bedrock of China's resistance.

The Marco Polo Bridge Incident of July 1937 marked the beginning of nationwide resistance. Owing to the CCP's foresight and persistence, the United Front was established and preserved, resulting in KMT-CCP cooperation across the frontlines. China's single-handed struggle with Japan signified the world's first large-scale anti-fascist resistance.

The CCP was China's main mobilizing and unifying force during the war. It successfully stirred the people to develop anti-Japanese bases in occupied and unoccupied areas; deployed innovative guerrilla warfare; promulgated correct theories of resistance and self-reliance; and preserved national unity despite KMT (factional) defeatism and obstruction.

The Japanese invaders inflicted great suffering on the Chinese people, including wanton slaughter; indiscriminate bombings; the abuse of women, children and forced labourers; wide-scale plunder; and bacterial and chemical warfare. This unprecedented record of war crimes marked the darkest page in the history of modern civilization.

When war broke out in Europe and the Pacific, China had already been resisting fascism for years. With its strategy of protracted warfare, China held down Japan's main fighting force on its soil. By thus precluding it from deployment elsewhere, China supported the Allies' "Europe first" strategy and made a critical contribution to defeating the Axis powers.

The steadfast resistance and sacrifices of the Chinese people for the sake of peace and justice won sympathy and support from the international community, prompting cooperation with and attracting aid from the Soviet Union and the United States as well as support from foreign individuals who sympathized with China's just cause.

The Chinese people were able to defeat a militarily superior enemy after 14 years of resistance, thanks to the CCP-led United Front. This unprecedented victory of a semi-colony over an imperialist power was a historical 


\section{Section title}

8 "Always remember history"

Conclusion

\section{Narrative outline}

turning point for the Chinese nation, marking the end of a century of "national humiliation" and the restoration of China's standing.

The war must be remembered to safeguard global peace and justice. Whilst promoting friendship with Japan, China remains on alert against Japanese right-wing forces that jeopardize the results of the war by whitewashing and distorting history. China will stick to peaceful development and join hands with all friendly nations for the sake of common prosperity.

The Chinese people must remember history, remain true to their original aspirations, embrace socialism with Chinese characteristics, and implement Xi Jinping Thought to secure ultimate "victory" and realize the "Chinese dream" of national rejuvenation. China will work with the people of all countries to build a "community of common destiny for mankind." 
In presenting this China-centred account emphasizing national unity, CCP steadfastness and inevitable victory, the narrative resembles that of the latest edition of the eighth-grade history textbook, discussed above. Japanese atrocities and Chinese victimhood do feature in the narrative, but they are once again confined to a single dark chapter in an otherwise upbeat narrative underscoring the agency of the Chinese people in achieving victory. Despite noting the KMT's moral failures and downplaying its diplomatic successes, the narrative is inclusive in that it acknowledges that the KMT played some positive role in cooperating with the CCP towards China's anti-fascist resistance. A notable difference from the textbook is that the exhibition narrative echoes Xi's speeches in placing a strong emphasis on the contemporary significance of history's "lessons." The Chinese people, whether at home or overseas, are told that they should unite under CCP leadership so they can realize their "Chinese dream." The international community, for its part, should acknowledge China's historic contribution to victory and justice and embrace Chinese notions of global governance to safeguard global peace.

\section{Formal diplomacy: commemoration initiatives at the United Nations}

$\mathrm{Xi}$ Jinping has repeatedly stressed the critical importance of the central CCP leadership at the highest level to the success of China's national strategies. A major institutional reform to strengthen and unify Party control over China's foreign policy was the establishment in 2018 of the Central Foreign Affairs Commission (CFAC). ${ }^{52}$ Organized directly under the Politburo and chaired by Xi personally, the CFAC serves as the central institution in charge of coordinating China's foreign policy between the Party, government and armed forces. Other manifestations of increased centralization of foreign policy under $\mathrm{Xi}$ are the elevation of Yang Jiechi 杨洁箎, China's foremost diplomat and CFAC director, to the Politburo of the CCP and the appointment of the incumbent foreign minister, Wang Yi 王毅, as state councillor. On the one hand, these changes have helped the CCP to introduce major new policies, including China's first neighbourhood policy and the Belt and Road Initiative in 2013, and new Chinese governance concepts, such as "major-power diplomacy" and "community of common destiny for mankind." On the other hand, China has also become an outspoken supporter of the existing global system under the United Nations (UN). According to Rosemary Foot, the UN is Beijing's multilateral venue of choice, because it accords China considerable status as a great power and global stakeholder, and the UN's foundational principles of sovereignty and legal equality closely match Chinese preferences. ${ }^{53}$

In 2015, taking its turn as president of the UN Security Council (UNSC), China initiated an "open debate" with the theme "Maintenance of international

52 The Central Foreign Affairs Commission replaced the former Central Leading Small Group on Foreign Affairs. See Hu, Weixing 2019, 13-14.

53 Foot 2014, 1088, 1095. 
peace and security: reflect on history, reaffirm the strong commitment to the purposes and principles of the Charter of the United Nations." In an advance note, Beijing expressed its hope that the debate would encourage member states to "reaffirm their commitment" to the principles of the UN Charter and create a "suitable atmosphere" for the commemoration of the 70th anniversary of the victory in the war against fascism and the founding of the UN. ${ }^{54}$ Urging member states to reflect deeply on history, China called on these states to uphold "the principles of sovereign equality and non-interference in internal affairs," commit to the "peaceful settlement of international disputes," "uphold democracy and the rule of law in international relations," and "pursue common development and win-win cooperation." By observing that the UN was "born out of the ashes of the Second World War," the note established a clear and direct link between the history of the war and Beijing's current visions of global governance.

Foreign Minister Wang Yi elaborated on these themes during the debate on 23 February 2015. ${ }^{55}$ Perhaps even more significant was Xi Jinping's keynote address before the UN General Assembly in September of that year. ${ }^{56}$ Reflecting on the history of the war, he drew attention to two points. First, as the main battlefront in the East during the Second World War, China made a historic contribution to the global war against fascism by not only rescuing the Chinese nation from Japanese aggression but thereby also aiding the European and Pacific war efforts. Second, as a result of this great contribution to peace, China was a principal founder of the UN, being "the first country to put its signature on the UN Charter." ${ }^{57}$ Indeed, the Nationalist diplomat Gu Weijun 顾维钧 (Wellington Koo) had been the first to sign the Charter on 26 June 1945, followed shortly thereafter by the CCP delegate, Dong Biwu 董必武. Photos of this historic event are displayed prominently in the War of Resistance Museum and in the National Museum in Beijing, and Xi and other Chinese officials have recalled the occasion in several important speeches. ${ }^{58}$ At the 56th Munich Security Conference in February 2020, for example, Wang Yi noted that "as the first founding member of the UN to sign its Charter, China has stayed true to the UN's founding aspirations and firmly defended the purposes of the Charter and international law." 59

54 Letter dated 3 February 2015 from the Chinese permanent representative to the secretary-general of the UN, UN S/2015/87.

55 Records of the 7389th meeting of the UN Security Council, 23 February 2015, 3-5. UN S/PV.7389, https://digitallibrary.un.org/record/788477. Accessed 1 November 2019.

56 "Working together to forge a new partnership of win-win cooperation and create a community of shared future for mankind." Statement by Xi Jinping at the 70th Session of the UN General Assembly, 28 September 2015, https:/gadebate.un.org/sites/default/files/gastatements/70/70_ZH_en.pdf. Accessed 1 November 2019.

57 Ibid., 6.

58 See, e.g., "Working together to build a community of shared future for mankind." Keynote speech by Xi Jinping at the UN Office at Geneva, 18 January 2017, http://www.china.org.cn/chinese/2017-01/25/ content_40175608.htm. Accessed 1 November 2019. Fieldnotes, Beijing, 3 October 2019.

59 "FM Wang Yi's speech at 56th Munich Security Conference." China Daily, 16 February 2020, http:/l www.chinadaily.com.cn/a/202002/16/WS5e490ce7a310128217277dc8.html. Accessed 18 February 2020. 
On the significance of history for the present and future, the Chinese leaders made two further two points. First, all member states should follow China's example of reaffirming their commitment to world peace and the founding principles of the UN. Second, to translate these principles into practice, member states should work together in building a "new type" of international relations featuring win-win cooperation and creating a "community of common destiny for mankind." 60 Thus, under Xi, history's "lessons" for the international community are framed in a forward-looking, moderate and generally constructive way; they do not emphasize historical wrongdoings or resentments, nor do they exclude any international actors from Chinese visions of global order. Presenting China as a principal founder and stakeholder of the post-war global order undergirds not only Beijing's diplomatic efforts to preserve the basic UN system but also its inherent right to propose reforms to that system. Following the increase of tensions with the United States in recent years, recalling the war's legacy in moral terms around dichotomies of peace versus aggression and harmony versus hegemony also allows the CCP to portray "hegemonic" global forces - mainly the United States - as disrupters of the UN-based multilateral order and hence as a "threat" to global peace. ${ }^{61}$ With Beijing's quest for "national greatness" being highly contingent upon regional stability and peace, this veiled warning is a reminder of how closely intertwined the domestic and international narratives are.

\section{A Paradigm Shift: Recounting Greatness}

The three cases analysed in this article bear testimony to the carefully planned and widely implemented decision of the central CCP leadership to reshape the basic interpretative paradigm of China's War of Resistance against Japan. The result is a highly unifying, empowering and aspirational representation of "national greatness" that remixes select elements of the previous two paradigms. In emphasizing China's "great victory," the new narrative departs from the dominant trope of the Deng/Jiang years, which was to portray China as a weak and passive victim of Japanese atrocities. At the same time, it differs from the earlier discourse under Mao by vesting primary agency in the united Chinese people rather than the revolutionary vanguard, and by framing the war around a moral (rather than Marxist-Leninist ideological) dichotomy of justice defeating evil. ${ }^{62}$ By highlighting the wartime cooperation between the $\mathrm{CCP}$ and the KMT, so studiously ignored during the Maoist era but gradually revived since, the narrative seeks to involve the entire "Chinese people" - including the

60 See the documents cited in notes $54-56,58-59$.

61 "Key quotes of Xi Jinping's speech at a symposium to commemorate WWII victory anniversary." CGTN, 3 September 2020, https://news.cgtn.com/news/2020-09-03/Xi-Jinping-s-key-quotes-atsymposium-marking-WWII-victory-anniversary-TurlSS2NWw/index.html; and Zhao, Minghao 2020a.

62 In terms of Brook's (2008) four "judgements," this represents a shift in judgement from partisanpolitical (via nationalistic) to moral. See also Zhang, Haipeng 2016. 
Chinese diaspora and the Taiwanese - into a single, pan-Chinese nationalist discourse. Instead of framing CCP-KMT relations in zero-sum terms or comparing their respective quantitative contributions to the war, $\mathrm{Xi}$ offers a qualitative assessment of their joint effort in which the CCP's success in achieving and maintaining national unity prevails as the decisive factor in China's ultimate victory.

The Chinese people's "victory" and "greatness" have thus become the central tenets of official Second World War remembrance in China, following a shift initiated under $\mathrm{Hu}$ and completed under Xi. Victimization and victory narratives were still competing for dominance in Hu-era speeches, textbooks and exhibitions; now, the emphasis is squarely on victory. This is not to suggest that victimization has lost its significance as a theme in the Chinese discourse on the war. On the contrary, just as the "revolutionary heroism" retained its relevance even after it was replaced as the main paradigm in the 1980s, so does its successor narrative remain a powerful trope in the public sphere today, as reflected both in the official remembrance of the Nanjing Massacre and in popular initiatives. ${ }^{63}$ The cases studied here make it very clear, however, that the victimhood theme is no longer central to the CCP's main message. In the newest textbooks and exhibitions, Chinese victimhood is confined to a single (if dreadful) chapter in an otherwise upbeat and inspiring narrative, while Chinese leaders have stopped mentioning wartime atrocities and suffering in their speeches. Museum exhibitions outside of China's wartime occupied areas, such as in the former Nationalist capital of Chongqing, pay virtually no attention to the Nanjing Massacre. ${ }^{64}$ A strong focus on resistance and heroism, not victimhood, also characterizes exhibitions at "Red" heritage sites across the country and at the National Museum in Beijing. ${ }^{65}$ Even at the Memorial Hall of the Victims of the Nanjing Massacre, the once almost exclusive focus on victimhood has been counterpoised by the 2015 addition of a major exhibition hall commemorating China's victory in the war. ${ }^{66} \mathrm{~A}$ similar trend can be observed in the once ubiquitous anti-Japanese rhetoric. Although Japan's past crimes and present right-wing inclinations remain sensitive and potentially inflammatory topics in China and the object of important historical "lessons," Japan's former role as the evil "other" has been minimized in museum narratives and removed altogether from school textbooks and official speeches.

As essentializing and unifying as the new central narrative is, it does feature slight variations in agency and emphasis depending on the audience primarily targeted. Two basic audiences can be distinguished. First and foremost is the "home" audience, the "Chinese people," which from Beijing's perspective includes both mainland Chinese and their overseas brethren in Taiwan and elsewhere in the world. This audience is targeted mainly through the school

63 For a recent op-ed in China's state media, see You and Shi 2020.

64 Fieldnotes, Chongqing, 15-18 October 2018, 17 April 2019, 21 September 2019.

65 Denton 2014, 52. Fieldnotes, Chongqing, 18 October 2018, 17 April 2019; Beijing, 3 October 2019.

66 Qian and Liu 2019, 95. 
curriculum and museum exhibitions, as analysed in this article, as well as through public commemorations and Chinese-language (social) media. The focus of these narratives is on the Chinese people and their great victory, but with a strong emphasis on the CCP as the indispensable force. The apparent goal is to legitimize and strengthen the Party's rule by using the people's war as a rallying point for pan-Chinese patriotism, unity and solidarity. "Red" history alone, as Beijing knows very well, could not provide a similarly inspiring and mobilizing force, because the divisive and traumatic legacies of China's revolution are alienating to not only most Taiwanese but also to many mainland Chinese who suffered during the turbulence of post-war China. The purpose of remembering the war is to deliver a message to the Chinese people that China cannot survive, let alone regain strength, without the CCP. A remarkable implication of using Second World War history for this purpose is that the "great victory" of 1945 has come to rival the revolution of 1949 as the central foundational event of modern China.

The other major target is the "external" audience, which comprises the international community and particularly those major powers that shape regional and global politics. This global audience is targeted primarily through diplomacy at major multilateral forums, such as the UN, but also at institutions like BRICS and the Shanghai Cooperation Organization as well as through public commemorations, war exhibitions and the media. ${ }^{67}$ In these representations, the primary agent is again the Chinese nation, but with a more statist focus emphasizing China's contribution to global peace and justice. The main purpose of remembering the war in the international context is to promote an image of the PRC as a peace-loving and responsible power, which has always stood on the "right" side of history as a "maker," and certainly not a "breaker," of the post-war international order and the values underpinning it. Claiming (co-)ownership of the UN system allows Beijing to advocate a return to the primacy of sovereignty and non-interference. This conservative "historicism" thus does not mean that China advocates the status quo: implied within it is an assertion of Beijing's right to propose reforms and to resolve its "unfinished business" in the East China Sea and Taiwan.

The pivot away from both the crude revolutionary rhetoric of the Maoist era and the resentful victimhood narratives of the Deng/Jiang years could be taken as a continuation of the trend towards the "normalization" and "globalization" of war historiography identified by Rana Mitter in $2010 .^{68}$ There are, however, two important reservations to this, suggesting that war memory in China cannot be easily placed on the same footing with war memory in other countries. First, the official Chinese narrative has become more, rather than less, exclusively

67 See, e.g., "China, Russia reiterate opposition to distorting history, whitewashing fascism." China Daily, 4 June 2015, http://www.chinadaily.com.cn/world/2015-06/04/content_20910931.htm. Accessed 1 November 2019.

68 Mitter 2010, 85, 91. 
Sino-centric under Xi, and hence anything but "globalized." In 2005, Hu Jintao spoke generously of the "solidarity" of the "anti-Fascist allies worldwide," but for $\mathrm{Xi}$ the war was won by the Chinese people, initially fighting alone and later "aided" by some "foreign governments and friends." Second, in line with the general trend of increased censorship and control under Xi, public war commemoration has been placed much more firmly under the central aegis of the $\mathrm{CCP}$, leaving the public and scholars alike minimal room to deviate from what it deems to be the "correct view of history." 69

With domestic and foreign challenges mounting now that China's "great rejuvenation" has entered its "critical stage," the CCP has observed that the stakes are high and the risk of failure is great. ${ }^{70}$ At what the Party regards as a vital hour in its history, it appears eager for the Chinese people to close ranks under its leadership and for the international community to accept China as a responsible yet equal partner. ${ }^{71}$ In a speech marking the 75 th anniversary of V-J Day, Xi emphasized that "the nation's great spirit" of patriotism and heroism, which had led the Chinese people to victory in the Second World War, "is invaluable today and can motivate the Chinese people to overcome all difficulties and obstacles and strive to achieve national rejuvenation." 72 The new paradigm of the war's commemoration was designed specifically to serve these goals. Aspirational, empowering and seemingly "normalized," it is premised on recounting China's national greatness in the past so as to establish and secure that greatness in the present and future. Under the new paradigm, China's discursive "other" is neither the Chinese people's erstwhile "class enemy" nor the "Japanese rightist" as such, but any external force that seeks to thwart China's claim to greatness and "ultimate victory." 73 Similarly, any Chinese national who willingly aids such subversive efforts risks being branded a traitor (hanjian 汉奸) and compared to Wang Jingwei, China's despised "Quisling." 74

69 "Zhonggong zhongyang guowuyuan yinfa 'xin shidai aiguo zhuyi jiaoyu shishi gangyao" ("Outline for the implementation of patriotic education in the new era" issued by the Central Committee of the Communist Party of China and the State Council), http://www.gov.cn/zhengce/2019-11/12/content 5451352.htm. Accessed 10 August 2020.

70 Ibid. See also "Xi Focus: Xi emphasizes 'struggles' to achieve national rejuvenation.” Xinhuanet, 3 September 2019, http://www.xinhuanet.com/english/2019-09/03/c_138362482.htm. Accessed 23 November 2019.

71 "Renmin wang ping: jiqu shengli qishi mingji heping jiaoyi" (People's Daily commentary: learn from victory and remember the benefits of peace). Renmin wang, 15 August 2020, http://opinion.people. com.cn/n1/2020/0815/c223228-31823283.html. Accessed 15 August 2020.

72 "Why China hasn't forgotten about the war against Japanese aggression." CGTN, 3 September 2020, https://news.cgtn.com/news/2020-09-03/Xi-delivers-speech-at-symposium-to-mark-WWII-victory-anniversaryTud3lrn8Y0/index.html. Accessed 4 September 2020.

73 "Key quotes of Xi Jinping's speech at a symposium to commemorate WWII victory anniversary." CGTN, 3 September 2020.

74 Zhao, Minghao 2020b; "Chinese-born Pompeo adviser blasted as 'traitor' in China." Nikkei Asian Review, 25 August 2020, https://asia.nikkei.com/Politics/International-relations/US-China-tensions/ Chinese-born-Pompeo-adviser-blasted-as-traitor-in-China. Accessed 25 August 2020. Comparisons to Wang Jingwei can be found on various Chinese blogs. 


\section{Conclusion}

The Chinese people have stood up under Mao, grown rich under Deng and are becoming strong under Xi. This is how China's paramount leader summed up seven decades of revolutionary history in his landmark "new era" speech of October $2017 .{ }^{75}$ A new era calls for a new discourse, one befitting current goals and ambitions, and this is precisely where Xi's recasting of Second World War memory fits in. Compared with the preceding paradigms of "revolutionary heroism" and "national victimhood," the new line is respectively more inclusive and empowering. It is also more tailored for international use, holding clear lessons - and implicit warnings - for the present and future. A key question will be how this more self-assertive and aspirational new discourse will hold up in the face of the mounting global pressures on China and the CCP.

This study has sought to contribute to the literature on war remembrance in China by laying out a fundamental, yet largely overlooked, shift in Chinese official discourse. The focused review of new representations in the school curriculum, museum exhibitions and formal diplomacy has begun to establish the scope and depth of this shift and to identify the substantive themes, actors, dichotomies and "lessons" that are central to the new narrative. Further research is needed to explore how this shift is manifesting in domains where the central leadership exercises less direct control, such as in localities outside of Beijing, social media and historiographical scholarship.

\section{Acknowledgements}

This study is a product of a collaborative project between the Chongqing Research Center for the Great Rear Area of the War of Resistance against Japanese Aggression at Southwest University (China) and the LeidenAsiaCentre at Leiden University (The Netherlands). I thank the LeidenAsiaCentre for initiating and advancing the project and the History College of Southwest University, where I completed a significant part of the field research, for its support and for hosting a joint conference on Second World War commemoration in September 2019. I am indebted to the conference participants and the two anonymous reviewers of The China Quarterly for their valuable suggestions and comments.

\section{Biographical note}

Dr Vincent K.L. CHANG is a lawyer and a historian of modern China. He holds concurrent positions at Leiden University and the LeidenAsiaCentre, The Netherlands, having previously worked at the History College of Southwest University, China. His research interests include the Second World War and the post-war period, historical memory, and China's historical and contemporary international relations. 


\begin{abstract}
摘要：自习近平担任中国最高领导人以来, 关于第二次世界大战, 尤其是 抗日战争的官方纪念活动在中国急速升温。中国对第二次世界大战的官方 叙事也随之发生了极大的变化。但是, 这些变化在很大程度上被学界所忽 视。本研究从中国的中学历史教材、战史博物馆、以及正式外交中选取三 个案例, 着力分析中国对第二次世界大战在中央层面的叙事嬗变。通过研 究发现, “民族受害”, 作为昔日的主导性修辞, 已不能代表当前中国共 产党对第二次世界大战的主流叙事。作为替代, 一种以 “民族胜利” 和 “民族伟大” 为核心修辞的抱负型叙事正在被精心实施。其目的是夯实中 国共产党的合法性并推进政策目标的实现。通过强调战时民族团结和国共 合作, 新的叙事为中国的战争努力提供了一个包容和统一的解释。在这样 的叙事之中, 1945 年抗战的最终胜利被赋予了与共产党 1949 年建立新中 国同等的重要地位, 被认为是 “民族复兴” 的关键历史转折点。这种日益 以中国为中心且中央进行控制的二战叙事对那些挑战中国寻求伟大的势力 发出了含蓄的警告。
\end{abstract}

关键词: 中国人民抗日战争; 第二次世界大战; 官方记忆; 爱国主义教育; 历 史教材; 博物馆叙事; 民族复兴

\title{
References
}

Brook, Timothy. 2008. "Collaboration in the history of wartime East Asia." Asia Pacific Journal: Japan Focus 6(7), 1-17.

Coble, Parks M. 2007. “China's 'new remembering' of the Anti-Japanese War of Resistance, 19371945." The China Quarterly 190, $394-410$.

Denton, Kirk A. 2014. Exhibiting the Past: Historical Memory and the Politics of Museums in Postsocialist China. Honolulu, HI: University of Hawai'i Press.

Foot, Rosemary. 2014. "'Doing some things' in the Xi Jinping era: the United Nations as China's venue of choice." International Affairs 90(5), 1085-1100.

Foot, Rosemary. 2019. "Remembering the past to secure the present: Versailles legacies in a resurgent China." International Affairs 95(1), 143-160.

Gries, Peter H. 2004. China's New Nationalism: Pride, Politics, and Diplomacy. Berkeley, CA: University of California Press.

Hatch, Walter. 2014. "Bloody memories: affect and effect of World War II museums in China and Japan." Peace and Change 39(3), 366-394.

Ho, Chui-fun Selina. 2019. Museum Processes in China: The Institutional Regulation, Production and Consumption of the Art Museums in the Greater Pearl River Delta Region. Amsterdam: Amsterdam University Press.

Hu, Jintao. 2005. "Speech on war victory commemoration." China Internet Information Center, 3 September, http://www.china.org.cn/english/2005/Sep/140771.htm. Accessed 1 November 2019.

$\mathrm{Hu}$, Weixing. 2019. "Xi Jinping's 'major country diplomacy': the role of leadership in foreign policy transformation." Journal of Contemporary China 28(115), 1-14.

Huang, Yunlong. 2017. "Bu bian Zhongguo lishi ba nianji shangce jiaokeshu zongti jieshao" (General introduction to the first volume of the eighth-grade textbook Chinese History). Lishi jiaoxue 19, 5559.

Li, Hongtao, and Shunming Huang. 2014. "'Chi hua' xushi yu wenhua chuangshang de jiangou: Renmin ribao Nanjing da tusha jinian wenzhang de neirong fenxi" ("Shameful" narratives and 
the construction of cultural wounds: content analysis of articles in People's Daily commemorating the Nanjing Massacre). Xinwen yu chuanbo yanjiu 1, 37-54.

Li, Xin. 2017. "Chouhen yu jiyi: Nanjing da tusha lishi jiaoyu zhong de qinggan yindao" (Hatred and memory: emotional guidance in the education of the history of the Nanjing Massacre). Nanjing shehui kexue 11, 129-134.

Liu, Yanjun. 2009. "Nanjing da tusha de lishi jiyi (1937-1985)" (Historical memory of the Nanjing Massacre (1937-1985)). Kangri zhanzheng yanjiu 4, 5-22.

Mao, Zedong. 1949. Lun lianhe zhengfu (On Coalition Government). Hong Kong: Xin minzhu chubanshe.

Mitter, Rana. 2000. "Behind the scenes at the museum: nationalism, history and memory in the Beijing War of Resistance Museum, 1987-1997.” The China Quarterly 161, 279-293.

Mitter, Rana. 2010. "Changed by war: the changing historiography of wartime China and new interpretations of modern Chinese history." Chinese Historical Review 17(1), 85-95.

Pozzi, Laura. 2020. "Local museum, national history: curating Shanghai's history in the context of a changing China (1994-2018).” International Journal of Heritage Studies. https://doi.org/10.1080/ 13527258.2020.1799060.

Qian, Fengqi, and Guo-Qiang Liu. 2019. "Remembrance of the Nanjing Massacre in the globalised era: the memory of victimisation, emotions and the rise of China." China Report 55(2), 81-101.

Reilly, James. 2011. "Remember history, not hatred: collective remembrance of China's War of Resistance to Japan.” Modern Asian Studies 45(2), 463-490.

Renmin jiaoyu chubanshe. 2017. Zhongguo lishi, ba nianji, shang ce (Chinese History, Grade 8, Vol. 1). Beijing: People's Education Press.

Rozman, Gilbert F. 2010. Chinese Strategic Thought toward Asia. New York: Palgrave MacMillan.

Varutti, Marzia. 2014. Museums in China: The Politics of Representation after Mao. Woodbridge: The Boydell Press.

Waldron, Arthur. 1996. "China's new remembering of World War II: the case of Zhang Zizhong." Modern Asian Studies 30(4), 945-978.

Wang, Guangtao. 2017. "Zhengzhi xushi, yanshuo kongjian yu Riben zhengfu dui Nanjing da tusha jiyi de caozuo" (Political narrative, discourse analysis and the Japanese government's manipulation of the memory of the Nanjing Massacre). Nanjing shehui kexue 8, 43-49.

Wang, Xiaokui. 2017. "Historical shifts in remembering China's 'Nanjing Massacre'." Chinese Studies in History 50(4), 324-334.

Wang, Zheng. 2008. "National humiliation, history education, and the politics of historical memory: patriotic education campaign in China.” International Studies Quarterly 52, 783-806.

Weatherley, Robert, and Coirle Magee. 2018. "Using the past to legitimise the present: the portrayal of good governance in Chinese history textbooks." Journal of Current Chinese Affairs 47(1), 41-69.

Xi, Jinping. 2015. "Address at the commemoration of the 70th anniversary of the Chinese people's War of Resistance against Japanese Aggression and the world anti-fascist war." China Daily, 3 September, https://www.chinadaily.com.cn/world/2015victoryanniv/2015-09/03/content_21783362. htm. Accessed 1 November 2019.

$\mathrm{Xi}$, Jinping. 2017. "Secure a decisive victory in building a moderately prosperous society in all respects and strive for the great success of socialism with Chinese characteristics for a new era." Speech at the CCP's 19th National Congress, 18 October, https://www.chinadaily.com.cn/china/ 19thcpcnationalcongress/2017-11/04/content_34115212.htm. Accessed 15 August 2020.

You, Yang, and Xucheng Shi. 2020. "Remembering history: Japanese soldiers' cruelty in China during World War II." CGTN, 13 August, https:/news.cgtn.com/news/2020-08-13/Remembering-historyJapanese-soldiers-cruelty-in-China-during-WWII-SV74xBrUas/index.html. Accessed 15 August 2020.

Zhang, Haipeng. 2016. "The two starting points of World War II: a reexamination from a global perspective." Journal of Modern Chinese History 10(1), 52-66.

Zhang, Qiang, and Robert Weatherley. 2013. "Owning up to the past: the KMT's role in the war against Japan and the impact on CCP legitimacy." Pacific Review 26(3), 221-242. 
Zhao, Minghao. 2020a. "US attempt to create "new order' aimed at maintaining hegemony." Global Times, 4 September, https://www.globaltimes.cn/content/1199930.shtml. Accessed 4 September 2020. Zhao, Minghao. 2020b. "Trump policy toward China skewed by academic fanatic." Global Times, 27 July, https://www.globaltimes.cn/content/1195800.shtml.

Zhao, Suisheng. 1998. "A state-led nationalism: the patriotic education campaign in post-Tiananmen China." Communist and Post-Communist Studies 31(3), 287-302. 